\title{
ANALISIS EFISIENSI TEKNIS USAHATANI PADI SAWAH APLIKASI PERTANIAN ORGANIK ( Studi Kasus Di Desa Sumber Ngepoh, Kecamatan Lawang ) Kabupaten Malang MT 2009 - 2010
}

\author{
Tien \\ Mahasiswa Program Doktor Ilmu Pertanian \\ Universitas Brawijaya
}

\begin{abstract}
The application of organic farming on rice farming in Indonesia is still new to know. The farming interested if efficiency economics. The meaning efficiency economics if the technical efficiency. This research aimed to evaluate the performance of organic rice farming systems, focusing on: (1) identifying the range of application of organic farming on rice farming, (2) analyzing the productivity and income from applying organic farming, and (3) analyzing the technical efficiency of applying organic farming and identifying factors that influence it.

The study was conducted in Malang Regency with take sample Sumber Ngepoh village, Lawang, Malang. This village is purposively taken because this is only a village in East Java which has obtained a certificate as a producer of organic rice from Organic Certification Agency. Furthermore, farmers did not interested application of organic farming. The sample of farmers 120 respondents selected by using non-proportionate stratified random sampling among those applying organic rice farming. The data are anal The results at the study stage show that there was diversity between implementing organic and agricultural organic farming system. This diversity reached only 8,33 percent application of organic rice farming of the total land area, while the rest was still in the transitional stage of applying organic system. The application of organic rice farming must independently be able to increase production and income of the farmer.

Judging from the level of technical efficiency, the application of organic rice farming is generally quite high, above the value of TE (technical efficiency) 0.8 , while applying an independent organic farming has higher technical efficiency than others. Determinant of technical efficiency is the practice of Sekolah Lapang or Field School and the independence of farmers in affording resources locally.

Keywords: Technical efficiency, independence of rice farming system, Organic farming applications.
\end{abstract}

\section{PENDAHULUAN}

Selama kurun waktu 40 tahun Indonesia telah mampu meningkatkan produksi beras sebesar $400 \%$, yakni dari 8,0 juta ton beras tahun 1963 menjadi 32 juta ton pada tahun 2004 (Deptan, 2005).

Faktor utama yang menentukan keberhasilan tersebut karena adanya program intensifikasi pertanian yang mengandalkan penerapan benih unggul dan penggunaan pupuk anorganik yang mampu meningkatkankan produktivitas padi per satuan hektar. Sejalan dengan perkembangan waktu, produktivitas padi saat ini relatif stagnan, bahkan segolongan masyarakat khawatir akan terjadinya ketidakberlanjutan produksi. Hal ini diduga karena terjadi degradasi kualitas lahan, sehingga pada beberapa tahun terakhir ini produksi padi nasional cenderung menurun (Pramono, 2004).

Penurunan produksi tersebut karena terjadinya pengurasan unsur hara dalam tanah secara cepat akibat praktek petani dalam menggunakan pupuk anorganik yang terus menerus dan berlebihan. Kondisi semacam ini mengakibatkan terjadinya penurunan kesuburan tanah karena semakin rendahnya kandungan bahan organik tanah (Tisdale et al., 1985; Karama, 2000).

Hasil penelitian Suyamto (2003), menunjukkan bahwa kandungan bahan organik tanah sawah di Jawa Timur diperkirakan 90\% tergolong rendah yaitu kurang dari $2 \%$. Oleh karena itu di masa mendatang selayaknya tidak bertumpu kepada penggunaan pupuk kimia sintetis, namun perlu dikembangkan 
inovasi teknologi yang mampu memperbaiki kesuburan lahan, meningkatkan produktivitas dan efisiensi usaha, serta memberikan nilai tambah sehingga dapat meningkatkan pendapatan rumah tangga petani.

Inovasi yang bisa ditempuh untuk mengembalikan kesuburan lahan adalah melalui sistem pertanian secara organik. Melalui pertanian organik ini diharapkan dapat mempertahankan kesuburan tanah, baik secara fisik, biologis maupun kimia sebagaimana ekosistem alami. Inovasi pertanian organik dalam usahatni padi diharapkan petani dapat memanfaatkan sumberdaya lokal, seperti pemberian pupuk organik dan pestisida nabati, rotasi tanaman, pengolahan tanah yang tepat, dan berbagai teknik konservasi lahan dan air. Di samping itu pertanian organik jika dikelola dengan baik mampu meningkatkan produktivitas lahan, ramah lingkungan dan produk dihasilkan aman bagi kesehatan manusia (Syekhfani, 2000).

Tanaman padi yang ditanam secara organik di Indonesia relatif masih baru, di samping itu informasi tentang usahatani padi organik masih terbatas. Oleh karena itu penelitian ini diarahkan untuk menganalisis produktivitas, pendapatan, dan efisiensi teknis usahatani padi organik dalam berbagai penerapannya.

Berdasarkan latar belakang diatas, maka penelitian ini ditujukan untuk mengetahui apakah usahatani padi sistem organik memberikan manfaat bagi petani ataukah efisensi teknis masih rendah.

\section{METODE PENELITIAN}

\section{Sample Penelitian}

Penelitian dilakukan di Kabupaten Malang dengan mengambil sample Desa Sumber Ngepoh Kecamatan Lawang yang ditentukan secara "purposive". Hal ini karena di lokasi tersebut merupakan satu-satunya desa di Jawa Timur yang telah memperoleh sertifikat sebagai produsen pangan organik dari Lembaga Sertifikasi Organik.

Sample petani diambil sebanyak 120 petani yang ditentukan dengan metode nonproportionate stratified random sampling berdasarkan strata macam aplikasi pertanian organik pada usahatani padi.

\section{Metode Analisis Data \\ Penentuan Macam Aplikasi Pertanian Organik}

Penentuan macam aplikasi pertanian organik pada usahatani padi sawah menggunakan skor dengan mengacu pada indikator pertanian organik SNI yang disesuaikan keadaan lokasi penelitian. Indikator tersebut meliputi aspek: lingkungan lahan, keadaan tanah, pengelolaan pertanian organik dan pola tanam, lama usahatani, penggunaan benih, Penggunaan bahan organik (kompos dan pestisida), penanganan panen dan pasca panen serta sertifikasi.

\section{Analisis Produktivitas}

Analisis produktivitas usahatani padi dari dilakukan dengan menggunakan 2 (dua) pendekatan, yaitu produktivitas parsial (produksi per hektar) dan produktivitas faktor total dengan ukuran angka indeks TFP (Total Factor Productivity). Produktifitas total faktor produksi adalah ukuran kemampuan seluruh jenis faktor produksi sebagai satu kesatuan faktor produksi agregat dalam menghasilkan output secara keseluruhan (output agregat) ( Chamber, 1988).

Dalam membandingkan produktivitas total faktor produksi dasar pembandinya adalah adalah usahatani padi yang menerapkan pertanian konvensional. Dalam studi TFP empiris, formula yang sering digunakan untuk membandingkan produktivitas faktor total (PFT) digunakan indeks Fisher dengan menggunakan Program TFPIP Versi 1.0.

\section{Analisis Pendapatan}

Pendapatan usahatani adalah selisih antara total penerimaan (Total Revenue) dengan biaya yang benar-benar dibayarkan. Guna mengetahui pendapatan usahatani padi digunakan rumus matematis sebagai berikut:

$E=P_{y} . Y-\left(r_{1} X_{1}+r_{2} X_{2}+r_{a} X_{a}+w X_{4}+Z_{2}\right)$

dimana :

$E$ = pendapatan usahatani (Rp)

$X_{1}=$ luas Lahan

$X_{\mathbf{z}}=$ jumlah benih yang dipergunakan $(\mathrm{kg})$

$X_{\mathrm{a}} \quad=$ jumlah pupuk yang dipergunakan $(\mathrm{kg})$

$X_{\mathbf{4}}=$ jumlah tenaga kerja luar keluarga (HKSP)

$r_{i}=$ harga input ke-i (Rp) dan nilai sewa lahan (Rp./ MT /ha)

$w \quad=$ upah tenaga kerja $(\mathrm{Rp}$ 


\section{Spesifikasi Model Fungsi Produksi Frontier}

Fungsi produksi usahatani ini dalam penelitian ini menggunakan Stochastic frontier production function dengan model yang dikembangkan oleh Battese dan Coelli (1995). Fungsi produksi frontier stokastik diasumsikan mempunyai bentuk Cobb-Douglas yang ditransformasikan ke dalam bentuk linear logaritma natural sebagai berikut :

$$
\begin{aligned}
& \ln Y=A_{0}+\alpha_{1} \ln X_{1}+\alpha_{2} \ln X_{2}+\alpha_{3} \ln X_{3}+\alpha_{4} \ln X_{4}+\beta_{1} D_{O M} \\
& +\beta_{2} D_{\text {OTM }}+\beta_{3} D_{T O M}+\beta_{4} D_{T O T M}+\beta_{5} D_{\text {MK1 }}+\beta_{6} D_{\text {MK2 }}+\left(V_{i}-U_{i}\right)
\end{aligned}
$$

Dimana :

$\mathrm{Y} \quad=$ jumlah produksi dalam satu musim tanam $(\mathrm{kg})$

$A_{0} \quad=$ konstanta

$\mathrm{i}=$ petani padi sawahke- $\mathrm{i}$

$\mathrm{X}_{1} \quad=$ luas lahan ( ha $)$

$\mathrm{X}_{2}=\operatorname{benih}(\mathrm{kg} / \mathrm{ha})$

$\mathrm{X}_{3}=$ nutrisi $(\mathrm{kg} / \mathrm{ha})$

$\mathrm{X}_{4} \quad=$ tenaga $\mathrm{kerja}(\mathrm{HKSP} / \mathrm{ha})$

$\mathrm{D}_{\mathrm{OM}}=$ dummy pertanian organik mandiri

$\mathrm{D}_{\mathrm{OM}}=1$, untuk pertanian organik mandiri

$\mathrm{D}_{\mathrm{OM}}=0$, untuk lainnyal

$\mathrm{D}_{\text {Отм }}=$ dummy pertanian organik tidak mandiri

$\mathrm{D}_{\text {отм }}=1$, pertanian organik tidak mandiri

$\mathrm{D}_{\text {Отм }}=0$, untuk lainnya

$\mathrm{D}_{\text {То м }}=$ dummy pertanian transisi organik mandiri

$\mathrm{D}_{\text {том }}=1$, untuk pertanian transisi organik mandiri

$\mathrm{D}_{\text {Tом }}=0$, untuk lainnya

$\mathrm{D}_{\text {т от м }}=$ dummy pertanian transisi organik tidak mandiri

$\mathrm{D}_{\text {тотм }}=1$, untuk pertanian transisi organik tidak mandiri

$\mathrm{D}_{\text {тотмм }}=0$, untuk lainnya

$\mathrm{D}_{\mathrm{MK}-1}=$ dummy Musim Kemarau pertama

$\mathrm{D}_{\mathrm{MK} \mathrm{-2}}=1$, untuk MK I

$\mathrm{D}_{\mathrm{MK}-2}=0$, untuk lainnya

$\mathrm{D}_{\mathrm{MK}-2}=$ dummy musim kemarau kedua

$\mathrm{D}_{\mathrm{MK}-1}=1$, untuk MK I

$\mathrm{D}_{\mathrm{MK}-1}=0$, untuk lainnya

$\mathrm{e}^{(\mathrm{g})} \quad=$ Erorr, dimana

$\mathrm{e}^{(\mathrm{g})} \quad=\mathrm{v}_{\mathrm{j}}-\mathrm{u}_{\mathrm{j}}$

$\mathrm{v}_{\mathrm{j}} \quad=$ a symmetric, normally distributed random error atau kesalahan acak model

$\mathrm{u}_{\mathrm{j}} \quad=$ one-side error term $\left(\mathrm{u}_{\mathrm{j}} \leq 0\right)$ atau peubah acak merepresen- tasikan in- efisiensi teknis dari contoh usahatani ke- i )

Model diestimasi dengan menggunakan metode Maximum Likelihood Estimation (MLE)

\section{Analisis Efisiensi Teknis}

Efisisiensi teknik dari produksi usahatani petani ke-i diestimasi dengan rumus sebagai berikut (Coelli, 1998) :

$$
\begin{aligned}
& T E_{i}=\frac{y_{i}}{Y_{i}^{*}}=\frac{\exp \left(x_{i i} \beta+v_{i}-u_{i}^{i}\right)}{\exp \left(x_{i} \beta+v_{i}\right)}=\exp \left(-u_{i}\right) \\
& \text { dimana } \quad \hat{u}_{i}=E\left(u_{i} \mid E_{i}\right) \\
& U_{i}=\delta_{0}+\sum_{j=1}^{m-1} \delta_{j} Z_{j i}+w_{i}
\end{aligned}
$$

dimana $y_{i}$ adalah produksi aktual dari pengamatan, dan $y^{*}$ adalah dugaan produksi frontier yang diperoleh dari fungsi produksi frontier stochastik. Efisiensi teknis untuk seorang petani berkisar antara nol dan satu.

Efisien usahatani diuji dengan Likelihood Ratio Test (LRT). Nilai LR test dihitung dengan menggunakan rumus :

$$
L R=-2\left[\ln \left\{\frac{L\left(H_{0}\right)}{L\left(H_{1}\right)}\right\}\right]
$$

Estimasi faktor-faktor atau sumber efisiensi teknis dipergunakan suatu model regresi linier dengan pendekatan Ordidary Least Square (OLS). Model yang digunakan adalah sebagai berikut :

$$
T E_{i}=\delta_{0}+\delta_{1} Z_{1}+\delta_{2} Z_{2}+\delta_{3} Z_{3}+\ldots \ldots . .+\delta_{6} Z_{6}
$$

Dimana : $T E_{i}=$ Efisiensi teknik,

$$
Z_{1}=\text { Umur }
$$

$Z_{2}=$ Pendidikan

$Z_{3}=$ Lama usahatani

$Z_{4}=$ Frek. Ikut Penyuluhan

$Z_{5}=$ Dummy Praktek Sekolah

Lapang

$Z_{6}=$ dummy Kemandirian

\section{HASIL DAN PEMBAHASAN \\ Macam Aplikasi Pertanian Organik}

Hasil pengukuran ragam aplikasi pertanian organik usahatani padi sawah yang dilakukan berdasarkan nilai score indikator 
penerapan pertanian organik disajikan pada Tabel 1.

Tabel 1. Macam Usahatani Berdasarkam Aplikasi Pertanian Organik.

\begin{tabular}{llll}
\hline $\begin{array}{l}\text { Jumlah } \\
\text { Skor }\end{array}$ & $\begin{array}{l}\text { Jumlah } \\
\text { Petani(\%) }\end{array}$ & Macam & $\begin{array}{l}\text { Singk } \\
\text { atan }\end{array}$ \\
\hline$>85$ & 16.67 & $\begin{array}{l}\text { Organik } \\
\text { Mandiri }\end{array}$ & OM \\
\hline $70-85$ & 11.67 & $\begin{array}{l}\text { Organik Tidak } \\
\text { Mandiri }\end{array}$ & OTM \\
\hline $55-<70$ & 27.50 & $\begin{array}{l}\text { Transisi } \\
\text { Organik } \\
\text { Mandiri }\end{array}$ & TOM \\
& 19.17 & $\begin{array}{l}\text { Transisi } \\
\text { Organik Tidak } \\
\text { Mandiri }\end{array}$ & TOT \\
\hline $40-<55$ & & $\begin{array}{l}\text { Konvensional } \\
\text { (non organik) }\end{array}$ & C \\
\hline$<40$ & 25.00 & & \\
\hline & & &
\end{tabular}

Berdasarkan Tabel 1 dapat diketahui adanya perbedaan nilai skore indikator usahatani padi yang dicapai petani pada berbagai aplikasi pertanian organik, yaitu score yang dicapai petani yang menerapkan pertanian organik mandiri, organik tidak mandiri, transisi organik mandiri dan transisi organik tidak mandiri secara berturutan adalah sebagai berikut 89,$53 ; 77,71 ; 61,24$ dan 48,09.

Pengertian mandiri dalam hal ini adalah bahwa petani menggunakan input produksi sepeti pupuk kandang dan benih berasal dari usahataninya sendiri dan atau kelompok petani. Kemandirian pada usahatani yang menerapkan pertanian organik dimaksudkan untuk menghindari ketergantungan pada sarana produksi.

Kemandirian petani akan penyediaan sarana produksi yang dipersyaratkan untuk menerapkan pertanian organik, meliputi : benih varietas lokal, pupuk organik dan pestisida nabati. Data selengkapnya disajikan dalam Tabel 2

Tabel 2. Macam Usahatani Padi Aplikasi Pertanian Organik Berdasarkan Rincian Indikator Pembentuknya

\begin{tabular}{|c|c|c|c|c|c|c|c|}
\hline \multirow[b]{2}{*}{$\begin{array}{c}\mathbf{N} \\
\mathbf{0}\end{array}$} & \multirow[b]{2}{*}{$\begin{array}{c}\text { Indika } \\
\text { tor }\end{array}$} & \multicolumn{6}{|c|}{$\begin{array}{c}\text { Rata-rata } \\
\text { Skor Aplikasi Pertanian Organik }\end{array}$} \\
\hline & & $\begin{array}{l}\mathbf{O} \\
\mathbf{M}\end{array}$ & $\begin{array}{l}\text { OT } \\
\text { M }\end{array}$ & $\begin{array}{l}\text { TO } \\
\text { M }\end{array}$ & $\begin{array}{l}\text { TO } \\
\text { TM }\end{array}$ & $\begin{array}{c}\text { Sco } \\
\text { re } \\
\text { tert } \\
\text { igi }\end{array}$ & $\begin{array}{c}\text { Sco } \\
\text { re } \\
\text { Rer } \\
\text { ata }\end{array}$ \\
\hline 1. & $\begin{array}{l}\text { Lingku } \\
\text { ngan } \\
\text { Lahan }\end{array}$ & $\begin{array}{l}15, \\
00\end{array}$ & $\begin{array}{l}15 \\
00\end{array}$ & $\begin{array}{l}7,5 \\
0\end{array}$ & 7,50 & $\begin{array}{l}15, \\
00\end{array}$ & $\begin{array}{l}11.2 \\
5\end{array}$ \\
\hline 2. & Keadaa & 14 , & 13 & 10 , & 9,24 & 15 , & 11.8 \\
\hline
\end{tabular}

\begin{tabular}{|c|c|c|c|c|c|c|c|}
\hline & $\mathrm{n}$ tanah & 38 & 57 & 15 & & 00 & 3 \\
\hline 3. & $\begin{array}{l}\text { Dukun } \\
\text { gan } \\
\text { teknolo } \\
\text { gi }\end{array}$ & $\begin{array}{l}7.5 \\
0\end{array}$ & $\begin{array}{l}6.0 \\
7\end{array}$ & $\begin{array}{l}7.8 \\
8\end{array}$ & 7.61 & $\begin{array}{l}10 \\
00\end{array}$ & 7.26 \\
\hline 4. & $\begin{array}{l}\text { Lama } \\
\text { aplikas } \\
\text { i }\end{array}$ & $\begin{array}{l}6.4 \\
0\end{array}$ & $\begin{array}{l}4.8 \\
6\end{array}$ & $\begin{array}{l}2.7 \\
0\end{array}$ & 2.87 & $\begin{array}{l}10 \\
00\end{array}$ & 4.21 \\
\hline 5. & $\begin{array}{l}\text { Kwalit } \\
\text { as } \\
\text { benih }\end{array}$ & $\begin{array}{l}6.6 \\
3\end{array}$ & $\begin{array}{l}8.2 \\
1\end{array}$ & $\begin{array}{l}7.7 \\
3\end{array}$ & 6.41 & $\begin{array}{l}10, \\
00\end{array}$ & 7.24 \\
\hline 6. & $\begin{array}{l}\text { Input } \\
\text { B.O } \\
\text { Sertifik } \\
\text { asi } \\
\end{array}$ & $\begin{array}{l}19 . \\
63\end{array}$ & $\begin{array}{l}20 . \\
00\end{array}$ & $\begin{array}{l}9.9 \\
2\end{array}$ & 7.50 & $\begin{array}{l}20, \\
00\end{array}$ & $\begin{array}{l}14.2 \\
6\end{array}$ \\
\hline 7. & $\begin{array}{l}\text { Panen- } \\
\text { Pasca } \\
\text { P }\end{array}$ & $\begin{array}{l}10 . \\
00\end{array}$ & $\begin{array}{l}10 . \\
00\end{array}$ & $\begin{array}{l}5.3 \\
6\end{array}$ & 5.00 & $\begin{array}{l}10 \\
00\end{array}$ & 7.59 \\
\hline 8. & $\begin{array}{l}\text { Keman } \\
\text { diri -an }\end{array}$ & $\begin{array}{l}10 . \\
00\end{array}$ & $\begin{array}{l}0.0 \\
0\end{array}$ & $\begin{array}{l}10 . \\
00\end{array}$ & 1.96 & $\begin{array}{l}10, \\
00\end{array}$ & 5.49 \\
\hline & $\begin{array}{l}\text { Total } \\
\text { Score }\end{array}$ & $\begin{array}{l}89, \\
53\end{array}$ & $\begin{array}{l}77 . \\
71\end{array}$ & $\begin{array}{l}61 . \\
24\end{array}$ & $\begin{array}{l}48.0 \\
9\end{array}$ & $\begin{array}{l}100 \\
, 00\end{array}$ & \\
\hline
\end{tabular}

Keterangan : OM = organik mandiri, OTM= organik tidak mandiri, TOM= transisi organik mandiri, TOTM = usahatani padi transisi organik tidak mandiri, $\mathrm{C}=$ Konvensional.

\section{Produktivitas}

Rata-rata produktivitas lahan usahatani padi dari berbagai aplikasi pertanian organik pada musim kemarau I 2009 (MK-I 2009), musim kemarau II 2009 (MK-II 2009), dan musim hujan 2010 (MH-2010), disajikan pada Tabel 3.

Table 3. Rata-Rata Produktivitas Lahan Usahatani Padi Berbagai Aplikasi Pertanian Organik dan Konvensional

\begin{tabular}{llllll}
\hline $\begin{array}{c}\text { Musi } \\
\mathbf{m} \\
\text { Tana } \\
\mathbf{m}\end{array}$ & \multicolumn{5}{c}{ Rerata Produksi/ha ( kw GKP / ha ) } \\
\cline { 2 - 6 } & OM & OTM & TOM & $\begin{array}{c}\text { T } \\
\text { OTM }\end{array}$ & \multicolumn{1}{c}{ C } \\
\hline M K & 6467. & 6278. & 6273. & 6074. & 5022. \\
1 & 50 & 57 & 55 & 61 & 82 \\
\hline M. K & 6860. & 6955. & 6819. & 6504. & 5443. \\
2 & 83 & 95 & 02 & 87 & 91 \\
\hline M. H & 5728. & 5580. & 5489. & 5218. & 4559. \\
& 33 & 95 & 02 & 75 & 96 \\
\hline Rerat & 6352. & 6271. & 6193. & 5932. & 4965. \\
a & 22 & 83 & 86 & 74 & 07 \\
\hline
\end{tabular}

Rata-rata produktivitas lahan usahatani padi menunjukkan produktivitas usahatani padi yang menerapkan pertanian organik mandiri lebih tinggi dari produktivitas usahatani padi yang menerapkan pertanian konvensional. Keadaan tersebut terjadi pada seluruh musim tanam. 
Produktivitas lahan diantara ketiga musim tanam menunjukkan bahwa produktivitas lahan ada MK 2 lebih tinggi dari produktivitas lahan pada MK1 dan MH.

Aplikasi pertanian organik dengan segala komponen teknologinya akan meningkatkan kesuburan tanah sehingga terjadi peningkatan produktivitas berdasarkan ukuran nilai indeks TFP (Tabel 4).

Tabel 4. Rerata Indeks Kuantitas Output, Input dan PFT.

\begin{tabular}{llll}
\hline \multirow{2}{*}{ PO } & \multicolumn{2}{l}{ Indeks Kuantitas } & Indeks \\
\cline { 2 - 3 } & Output & Input & TFP \\
\hline OM & 1.2680 & 0.9020 & 1.4060 \\
OTM & 0.9863 & 0.9706 & 1.0162 \\
TOM & 0.9877 & 1.2138 & 0.8137 \\
TOTM & 0.9577 & 0.9565 & 1.0012 \\
C & 1.0000 & 1.0000 & 1.0000 \\
\hline
\end{tabular}

Usahatani padi yang menerapkan pertanian organik mandiri mencapai indeks TFP: 1,41 , nilai ini lebih tinggi karena produktivitas lebih tinggi dengan input lebih rendah dari usahatani padi konvensional.

\section{Pendapatan Usahatani}

Pengukuran pendapatan usahatani digunakan pendekatan analisis finansial dan pendapatan yang benar-benar dikleuarkan petani. Berkaitan dengan penggunaan pupuk dan pestisida bervariasimu, sebagian petani dalam memenuhi kebutuhan pupuk organik dengan menggunakan limbah ternak atau membeli kepada petani lain anggota kelompok tani organik, dan untuk keperluan pestisida nabati umumnya membeli pada kelompok tani.

Pendapatan usahatani padi berbagai aplikasi pertanian organik berdasarkan disajikan dalam Tabel 5 .

Tabel 5. Pendapatan usahatani Padi Sawah Berbagai Aplikasi Pertanian Organik

Keterangan : lihat Tabel 2

\begin{tabular}{llllll}
\hline \multicolumn{7}{c}{ Rerata Rupiah per /ha } \\
\cline { 2 - 6 } Uraian & OM & $\begin{array}{l}\text { OT } \\
\text { M }\end{array}$ & $\begin{array}{l}\text { TO } \\
\text { M }\end{array}$ & $\begin{array}{l}\text { T } \\
\text { OT }\end{array}$ & $\mathbf{C}$ \\
& & & & $\mathbf{M}$ & \\
\hline Penerima & 1567 & 15492 & 14391 & 1345 & 1098 \\
an & 8083 & 857 & 378 & 7160 & 1470 \\
\hline & 771 & 855 & 897 & 946 & 922 \\
Biaya & 324 & 161 & 545 & 250 & 584 \\
Finansial & 7 & 7 & 9 & 0 & 1 \\
\hline Biaya & 711 & 798 & 816 & 865 & 848 \\
Riil & 910 & 107 & 022 & 467 & 327 \\
\hline
\end{tabular}

\begin{tabular}{llllll}
\hline & 6 & 2 & 2 & 0 & 4 \\
\hline $\begin{array}{l}\text { Pendapat } \\
\text { an }\end{array}$ & 7964 & 69412 & 541591 & 3994 & 1755 \\
financial & 836 & 39 & 9 & 660 & 629 \\
\hline $\begin{array}{l}\text { Pendapat } \\
\text { an riil }\end{array}$ & 8558 & 75117 & 623115 & 4802 & 2498 \\
\hline
\end{tabular}

Tabel 5 menunjukkan bahwa secara umum baik pendapatan finansial maupun pendapatan riil pada usahatani padi aplikasi pertanian organik mandiri lebih tinggi dari lainnya. Ada kecenderungan semakin menerapkan pertanian organic semakin tinggi pendapatannya. Hal ini karena disebabkan karena penerimaan pada usahatani padi yang menerapkan pertanian lebih tinggi.

\subsection{Efisiensi Teknis}

Hasil estimasi fungsi produksi frontier stochastik dalam bentuk Cobb-Douglas diestimasi menggunakan MLE disajikan pada Tabel 6

Tabel 6. Hasil Estimasi MLE Peubah Fungsi Produksi Frontier Stokastik.

\begin{tabular}{|c|c|c|c|c|}
\hline $\begin{array}{l}\text { Variab } \\
\text { el }\end{array}$ & $\begin{array}{l}\text { Pe } \\
\text { ub } \\
\text { ah }\end{array}$ & $\begin{array}{l}\text { Koefisi } \\
\text { en }\end{array}$ & $\begin{array}{l}\text { Standa } \\
\text { rd } \\
\text { error }\end{array}$ & t-ratio \\
\hline $\begin{array}{l}\text { Interse } \\
\mathrm{p} \\
\text { Lahan }\end{array}$ & $\beta_{0}$ & 7.8032 & 0.4877 & $\begin{array}{l}15.9999 * * \\
* *\end{array}$ \\
\hline benih & $\beta_{1}$ & 0.9799 & 0.0902 & $\begin{array}{l}10.8671 * * \\
* *\end{array}$ \\
\hline Nutrien & $\beta_{2}$ & -0.4166 & 0.0226 & $\begin{array}{l}18.4619 \\
* * * *\end{array}$ \\
\hline $\begin{array}{l}\text { Tenaga } \\
\text { Kerja }\end{array}$ & $\beta_{3}$ & -0.0077 & 0.0256 & $0.2989^{\mathrm{ns}}$ \\
\hline $\begin{array}{l}\text { Dumm } \\
\text { y OM }\end{array}$ & $\beta_{4}$ & 0.4603 & 0.0765 & $\begin{array}{l}6.0171 \\
* * * *\end{array}$ \\
\hline $\begin{array}{l}\text { Dumm } \\
\text { y OTM }\end{array}$ & $\beta_{5}$ & 0.0887 & 0.0267 & $\begin{array}{l}3.3246 * * * \\
*\end{array}$ \\
\hline $\begin{array}{l}\text { Dumm } \\
\text { y TOM }\end{array}$ & $\beta_{6}$ & 0.1033 & 0.0305 & $\begin{array}{l}3.3895 * * * \\
*\end{array}$ \\
\hline $\begin{array}{l}\text { Dumm } \\
\mathrm{y} \\
\text { TOTM }\end{array}$ & $\beta_{7}$ & 0.0318 & 0.0100 & $\begin{array}{l}3.1649 * * * \\
*\end{array}$ \\
\hline $\begin{array}{l}\text { Dumm } \\
\text { y MK1 }\end{array}$ & $\beta_{8}$ & 0.0441 & 0.0124 & $\begin{array}{l}3.5667 * * * \\
*\end{array}$ \\
\hline \multirow[t]{2}{*}{$\begin{array}{l}\text { Dumm } \\
\text { y MK2 }\end{array}$} & $\beta_{9}$ & 0.0916 & 0.0124 & $\begin{array}{l}7.4163 * * * \\
*\end{array}$ \\
\hline & $\beta_{10}$ & 0.0804 & 0.0099 & $\begin{array}{l}8.1529 * * * \\
*\end{array}$ \\
\hline $\begin{array}{l}\text { Sigma- } \\
\text { square } \\
\text { (Varian } \\
\text { s) }\end{array}$ & $\sigma^{2}$ & 0.0533 & 0.0129 & $\begin{array}{l}4.1413 * * * \\
*\end{array}$ \\
\hline Gamm & $\gamma$ & 0.9909 & 0.0029 & $346.38 * * *$ \\
\hline
\end{tabular}


a

log likelihood function $=533.4542$

LR test of the one-side error $=188.0211$

Keterangan : $* * * *=$ menunjukkan signifikan pada $\alpha$ $=1 \%$

Jika nilai $\gamma=1$ berarti model frontier sempurna , tanpa ada kesalahan model ( $\mathrm{v}$ ). Ternyata nilai taksiran $\gamma$ dalam model secara statistic $>0(\gamma=$ 0.9909 ). Hal ini menunjukkan keragaman model fungsi produksi frontier yang digunakan, variasi produksi usahatani padi di lokasi penelitian terjadi bukan karena faktor kebetulan, tetapi aktual terutama karena faktor inefisiensi teknis.

Jadi terbukti bahwa perbedaan fungsi produksi Cobb-Douglas mampu dengan baik menjelaskan data yang ada tentang terjadinya fenomena in-efisiensi teknis pada usahatani padi tersebut. Selanjutnya hasil perhitungan nilai LR test parameter retriksi $=188.02$ yang nilainya lebih besar dari nilai kritis dari Tabel Kodde and Palm $\chi_{10}^{2}=22.53$ pada tingkat signifikan $1 \%$ artinya ada efek in-efisiensi dalam model yang sifatnya stochastic, fakta ini mengindikasikan bahwa petani padi belum full efisien dalam melaksanakan usahataninya.

Jika $\sigma_{\mathrm{u}}^{\mathbf{z}}=\mathbf{0}$ berarti semua usahatani yang dilakukan petani adalah 100 persen efisien. Ternyata berdasarkan hasil analisis menunjukkan varian > 0, dengan demikian dapat disimpulkan tidak ada bukti bahwa tidak semua usahatani yang dilakukan petani 100 persen efisien, dimana nilai parameter $\sigma 2$ adalah 0.0533 secara statistik signifikan pada tingkat $\alpha=1 \%$ menunjukkan bahwa variasi produksi yang disumbangkan oleh in-efisiensi teknis adalah sebesar $5.33 \%$.

Faktor-faktor produksi meliputi lahan, tenaga kerja mempunyai koefisien yang positif dan berpengaruh nyata terhadap produksi, sedangkan faktor produksi pupuk yang diukur dengan nutrient pengaruhnya tidak nyata. Faktor produksi benih mempunyai koefisien yang negatif dan berpengaruh nyata terhadap produksi. Variabel dummy berbagai aplikasi pertanian menunjukkan adanya pengaruh positif yang signifikan secara statistik terhadap produksi dengan nilai koefisien secara berturutturut 0,$0887 ; 0,1033 ; 0,0318$ dan 0,0441 .

Hasil penelitian ini juga menunjukkan adanya pengaruh dari musim dummy MK-I dan dummy MK-II menunjukkan adanya pengaruh positif yang signifikan secara statistik terhadap intersep dari fungsi produksi frontier dengan nilai koefisien secara berturut-turut 0.0804 dan 0.0916. Hal ini mengungkapkan adanya perbedaan tingkat produksi rata-rata antara musim, dimana pada musim kemarau I dan II menghasilkan produksi secara berturut-turut $8,04 \%$ dan $9.16 \%$ lebih tinggi dibandingkan pada musim hujan.

Distribusi indeks efisiensi teknis tertinggi dicapai pada nilai indeks 95 - 98 dan jumlah terbanyak dicapai oleh usahatani padi aplikasi pertanian organik mandiri, selanjutnya secara berturut-turut indeks TE adalah 58,33; 38,10; 47,48 dan 42,03. Distribusi efisiensi teknis usahatani padi tertera pada Tabel 7.

Tabel 7. Distribusi Efisiensi Teknis (TE) Usahatani Padi

\begin{tabular}{llllll}
\hline Range & \multicolumn{6}{l}{ Frekuensi Relatif (\%) } \\
\cline { 2 - 6 } $\begin{array}{l}\text { Efisiensi } \\
\text { Teknis }\end{array}$ & OM & OTM & TOM & TO & C \\
\hline $50-80$ & - & - & 2,02 & 4,35 & 14,44 \\
$>80-90$ & 6,67 & 11,90 & 12,12 & 15,94 & 28,89 \\
$>\quad 90-$ & 8,33 & 19,05 & 10,10 & 11,59 & 17,78 \\
95 & 58,33 & 38,10 & 47,48 & 42,03 & 16,67 \\
$>95-98$ & 26,67 & 30,95 & 28,28 & 26,09 & 22,22 \\
$\geq 98$ & & & & & \\
\hline
\end{tabular}

Berdasarkan nilai TE yang diperoleh, maka dapat dihitung kesenjangan rata-rata produktivitas aktual dan potensial yang bisa dicapai. (Tabel 8).

Tabel 8. Kesenjangan Produktivitas Padi Aplikasi Pertanian Organik

\begin{tabular}{|c|c|c|c|c|c|}
\hline $\begin{array}{c}\mathbf{M} \\
\mathbf{T}\end{array}$ & & TE & $\begin{array}{c}\mathbf{Y}-\mathbf{a c t} \\
(\mathbf{k g})\end{array}$ & $\underset{(\mathbf{k g})}{\text { Ymax }}$ & $\begin{array}{c}\text { Gap } \\
\text { Hasil } \\
\text { Y max - } \\
\text { Y }(\mathbf{k g})\end{array}$ \\
\hline $\mathrm{M}$ & & 0.9 & 6467.5 & 6649.8 & \\
\hline $\mathrm{K}$ & OM & 73 & 0 & 0 & 182.30 \\
\hline - & OT & 0.9 & 6278.5 & 6494.1 & \\
\hline \multirow[t]{7}{*}{1} & $\mathrm{M}$ & 67 & 7 & 2 & 215.55 \\
\hline & $\mathrm{TO}$ & 0.9 & 6273.5 & 6509.8 & \\
\hline & $\mathrm{M}$ & 64 & 5 & 0 & 236.25 \\
\hline & TO & 0.9 & 6074.6 & 6300.3 & \\
\hline & $\mathrm{TM}$ & 64 & 1 & 1 & 225.70 \\
\hline & & 0.9 & 4864.4 & 5405.3 & \\
\hline & $\mathrm{C}$ & 00 & 8 & 9 & 540.91 \\
\hline $\mathrm{M}$ & & 0.9 & 6860.8 & 7117.9 & \\
\hline $\mathrm{K}$ & $\mathrm{OM}$ & 64 & 3 & 9 & 257.15 \\
\hline - & OT & 0.9 & 6955.9 & 7214.6 & \\
\hline \multirow[t]{6}{*}{2} & M & 64 & 5 & 1 & 258.65 \\
\hline & TO & 0.9 & 6819.0 & 7063.6 & \\
\hline & $\mathrm{M}$ & 65 & 2 & 5 & 244.63 \\
\hline & TO & 0.9 & 6504.8 & 6705.8 & \\
\hline & $\mathrm{TM}$ & 70 & 7 & 1 & 200.94 \\
\hline & $\mathrm{C}$ & 0.9 & 5285.0 & 5647.3 & 362.29 \\
\hline
\end{tabular}




\begin{tabular}{llllll}
\hline & & 36 & 2 & 1 & \\
\hline $\mathrm{M}$ & & 0.9 & 5728.3 & 6007.0 & \\
$\mathrm{H}$ & $\mathrm{OM}$ & 54 & 3 & 8 & 278.75 \\
\cline { 2 - 6 } & $\mathrm{OT}$ & 0.9 & 5580.9 & 5952.7 & \\
$\mathrm{M}$ & 38 & 5 & 7 & 371.82 \\
\hline & TO & 0.9 & 5489.0 & 5985.4 & \\
$\mathrm{M}$ & 17 & 2 & 0 & 496.38 \\
\hline & TO & 0.8 & 5218.7 & 5830.2 & \\
$\mathrm{TM}$ & 95 & 5 & 0 & 611.46 \\
\hline & & 0.8 & 4367.3 & 5139.2 & \\
& $\mathrm{C}$ & 50 & 7 & 2 & 771.85 \\
\hline
\end{tabular}

Keterangan : lihat Tabel 2.

Berdasarkan tabel 8 menunjukkan bahwa kesenjangan produksi usahatani padi yang menerapkan petanian organik murni lebih rendah dibandingkan dengan kesenjangan usahatani padi lainnya. Dan usahatani padi yang menerapkan petanian konvensional menunjukkan kesenjangan hasil yang paling tinggi karena keadaan tanah semakin tidak kondusif bagi tanaman sehingga apikasi pertanian konvensional membutuhkan penggunaaan pupuk dan pestisida yang lebih banyak. Faktor yang mempengaruhi efisiensi teknis disajikan dalam Tabel 9.

Tabel 9. Hasil Regresi Linier Berganda Faktor Yang Mempengaruhi efisiensi Teknis Usahatani Padi

\begin{tabular}{lllll}
\hline Variabel & $\beta$ & t hit & Sig. & Ket. \\
\hline Konstanta & 0.328 & 1.005 & 0.317 & $\begin{array}{l}\text { Non- } \\
\text { sig }\end{array}$ \\
\hline Umur & 0.001 & 0.124 & 0.901 & $\begin{array}{l}\text { Non- } \\
\text { sig }\end{array}$ \\
\hline Pendidikan & 0.019 & 1.221 & 0.225 & $\begin{array}{l}\text { Non- } \\
\text { Sig }\end{array}$ \\
\hline $\begin{array}{l}\text { Pengalaman } \\
\text { usahatani }\end{array}$ & 0.036 & 0.840 & 0.402 & $\begin{array}{l}\text { Non- } \\
\text { sig }\end{array}$ \\
\hline $\begin{array}{l}\text { Frekuensi } \\
\text { Ikut }\end{array}$ & 0.001 & 0.270 & 0.978 & $\begin{array}{l}\text { Non- } \\
\text { sig }\end{array}$ \\
$\begin{array}{l}\text { Penyuluhan } \\
\text { Praktek }\end{array}$ & 0.393 & 2.997 & 0.003 & Sig \\
$\begin{array}{l}\text { Sekolah } \\
\text { Lapang }\end{array}$ & & & & \\
\hline Kemandirian & 0.330 & 3.153 & 0.002 & Sig \\
\hline R square & $=$ & & Ftabel & $=3,19$ \\
& 0.268 & & $1 \%$ & \\
\hline $\begin{array}{l}\text { Adjusted } \\
\text { square }\end{array}$ & $\begin{array}{l}\text { R } \\
\text { F hitung }\end{array}$ & & $\begin{array}{l}\text { Ftabel } \\
5 \%\end{array}$ & $=2,30$ \\
\hline & 6.896 & & & \\
\hline
\end{tabular}

Hasil uji regresi menunjukkan bahwa menunjukkan bahwa nilai $\mathrm{R} 2=0.268$, artinya variasi efisiensi teknis hanya dapat dijelaskan oleh variabel bebas dalam model sebesar 26.8
$\%$, sedangkan sisanya dijelaskan oleh variabel lain. Rendahnya koefisien determinasi ini bukan berarti model kurang baik, karena diduga varibel bebas yang tidak masuk dalam model dimungkinkan variabel yang tidak dapat dikontrol. Disamping itu masih ada dua varibel bebas yang pengaruhnya nyata. Variabel praktek Sekolah Lapang dan kemandirian pertanian organik mempunyai pengaruh positif dan signifikan secara statistik terhadap peningkatan efisiensi teknis. Kedua variabel ini sangat tepat sebagai instrumen kebijakan peningkatan efisiensi teknis usahatani padi.

\section{Kesimpulan}

Berdasarkan hasil penelitian dapat dibuat beberapa kesimpulan berikut :

1. Pada lokasi penelitian, petani yang menerapkan pertanian organik hanya 11,67 persen, sedangkan sisanya masih dalam taraf transisi dan konvensional.

2. Penerapan pertanian organik pada usahatani padi mampu meningkatkan produksi dan pendapatan petani.

3. Tingkat efisiensi teknik, usahatani padi aplikasi pertanian organik cukup tinggi yakni di atas nilai TE (technical efficiency) 0.8 , dan petani yang menerapkan pertanian organik secara mandiri mencapai efisiensi teknis lebih tinggi dibandingkan lainnya.

4. Faktor penentu efisiensi teknis adalah dilaksanakannya praktek Sekolah Lapang (SL) dan kemandirian petani dalam mengusahakan sumberdaya (faktor produksi) secara lokal.

\section{Saran}

Berdasarkan hasil penelitian menunjukkan bahwa variabel praktek Sekolah Lapang dan kemandirian pertanian organik mempunyai pengaruh positif dan signifikan secara statistik terhadap peningkatan efisiensi teknis, dengan demikian disarankan adanya kebijakan pemerintah untuk meningkatkan frekuensi praktek Sekolah Lapang dan usaha untuk memfasilitasi kemandirian petani dalam penyediaan sarana produksi secara lokal.

\section{DAFTAR PUSTAKA}

Andoko, A. 2004. Budidaya Padi Secara Organik. Penebar Swadaya. Jakarta.

Aigner, D.J., C.A.K. Lovell, and P. Schmidt. 1977. Formulation and Estimation of Stochastic Frontier Production 
Function Models. Journal of Econometrics. 6:21-37.

Arifin, B. 2004. Analisis Ekonomi Pertanian. Kompas. Jakarta

Arifin dan Krismawati (2009), Sumber-sumber bahan organik. Balai Pengkajian Teknologi Pertanian. Jakarta

Battese, G.E. and T.J. Coelli. 1995. A Model for Technical Efficiency Effects in a Stochastic Frontier Production Function for Panel Data. Empirical Economics.3: 153 - 169.

Battese, G.E. and T.J. Coelli. 1988. Prediction of Firm Level Technical Efficiencies with A Generalized Frontier Production Function and Panel Data. Journal of Econometrics. 38:387-399.

Bedassa, T and S Krisnamoorthy. 1997. Technical efficiency in Paddy Farm of Tamil Nadu. : An Analysis Based on Farm Size and Ecological Zone. Agricultural Economic, 16: 185-192.

Chambers, Robert G. 1988. Applied Production Analysis : A Dual Approach. Chambridge University Press, Chambridge.

Coelli, T.J., D.S.P. Rao, and G.E. Battese. 1998. An Introduction to Efficiency and Productivity Analysis. Kluwer Academic Publisher, Boston.

Dabbert, S and P. Madden, 1986. The Transition to Organic Agriculture : A. Multi Year Simulation. Model of a Pensiylvania Farm. American Journal of Alternative Agriculture. 14(3):109121.

DepTan. 2005. 100 years of Departement of Agriculture. Departemen Pertanian Republik Indonesia. Jakarta.

Giannakas, Konstantinos, Kien C. Tran and Vangelis Tzouvelekas. 2003. On The Choice of Functional Form in Stochastic Frontier Modeling. Empirical Economics. 28:75-100.

Karama, S. 1994. Pembangunan Pertanian yang Efektif dan Berkelanjutan Menyongsong 2020. Makalah pada Seminar Kebijaksanaan Pendidikan Tinggi. Dies Natalis ke-45 UGM, 2021 Des. 1994.

Olaoye, A.O. 1985. Total Factor Productivity Trends in Nigerian Manufacturing. Nigerian Journal of Economic and Social Studies. Vol.27(3):317-345.
Pramono .2004. Pertanian Organik Suatu Harapan dicapainya pertanian ramah lingkungan.

Rutkauskas, J. and E. Paulaviciene. 2005. Concept of Productivity in Service

Sector. ISSN1392-2785 Engineering Economics. Vol. 43(3).

Sukiyono, K. 2004. Analisa Fungsi Produksi dan Efisensi Teknis : Aplikasi Fungsi Produksi Frontier Pada Usahatani Cabai di Kecamatan Selupu Rejang, Kabupaten Rejang Lebong.

Suyamto. 2003. Pemetaan Kesuburan Tanah Lahan Sawah dan Sistem Produksi Padi di Jawa Timur. Dinas Pertanian Propinsi Jawa Timur, Balai Pengkajian Teknologi Pertanian Jawa Timur.

Syekhfani. 2000. Pertanian Organik: Suatu Alternatif Menuju Sistem Pertanian Berkelanjutan (Ditinjau dari Aspek Kesuburan Tanah). Makalah disampaikan pada Temu Teknologi. Dinas Pertanian Tanaman Pangan Propinsi Jawa Timur di Bedali Lawang 19 Oktober 2000.

Tisdale, S.L., W.L. Nelson, and J.D. Beaton. 1985. Soil fertility and Fertilizers. 4th ed. Macmillan Pub. Co., New York. $754 \mathrm{p}$.

Widodo, S. 1989. Production efficiency of Rice Farmer in Java Indonesia. Gajah Mada University Press. Jogyakarta.

Wijayanti. 2005. Evaluasi Kelayakan Pengembangan Usahatani Padi Organik Beoririentasi Bisnis di Kabupatene Sleman. DIY. Jurnal Agros 6 (2): 40-50.

\section{Lampiran 1 : Divinisi Operasional Macam Usahatani Padi}

Aplikasi pertanian organik mandiri :

Usahatani padi yang menerapkan pertanian organik dengan menggunakan pupuk organik dan pestisida nabati yang pengadaan dan pembuatannya oleh petani.

Aplikasi pertanian organik tidak mandiri

Usahatani padi yang menerapkan pertanian organik, dengan menggunakan pupuk organik dan pestisida nabati, tetapi pengadaan dan pembuatannya tidakdilakukan oleh petani.

Aplikasi pertanian transisi ke organik mandiri 
Usahatani padi yang menerapkan pertanian transisi organik dengan menggunakan pupuk organik dan non-organik serta pestisida nabati yang pengadaan dan pembuatannya oleh petani.

Aplikasi pertanian transisi ke organik tidak mandiri

Usahatani padi yang menerapkan pertanian transisi organik dengan menggunakan pupuk organik dan non-organik serta pestisida nabati, tetapi pengadaan dan pembuatannya tidak dilakukan oleh petani

Aplikasi pertanian konvensional sebagai control, yaitu

\begin{tabular}{|c|c|c|c|c|c|}
\hline \multirow{3}{*}{$\begin{array}{l}\text { Macam } \\
\text { P O }\end{array}$} & \multicolumn{3}{|c|}{ MT $2009-2010$} & \multirow{3}{*}{$\begin{array}{l}\text { Total } \\
\text { T.K } \\
\text { (HKSP } \\
\text { /ha) }\end{array}$} & \multirow{3}{*}{$\begin{array}{l}\text { Rera } \\
\text { ta } \\
(\mathrm{kg} \\
/ \mathrm{ha})\end{array}$} \\
\hline & MK & MK & & & \\
\hline & -1 & -2 & MH & & \\
\hline Organik & 218. & 233. & 247. & & 232. \\
\hline M & 08 & 28 & 48 & 698.84 & 95 \\
\hline \multicolumn{6}{|l|}{ Organik } \\
\hline Tidak & 208. & 227. & 240. & & 225 . \\
\hline M & 03 & 24 & 18 & 675.45 & 15 \\
\hline Transisi & 243. & 265. & 289. & & 266. \\
\hline $\begin{array}{l}\text { Or.Man } \\
\text { diri }\end{array}$ & 81 & 03 & 22 & 798.06 & 0 \\
\hline Transsi & 234. & 252. & 275. & & \\
\hline $\begin{array}{l}\text { OT.Man } \\
\text { diri }\end{array}$ & 61 & 6 & 22 & 762.45 & 254. \\
\hline \multirow[t]{3}{*}{ Conv } & $\begin{array}{l}234 . \\
25\end{array}$ & $\begin{array}{l}250 . \\
50\end{array}$ & $\begin{array}{l}267 . \\
51\end{array}$ & 752.26 & $\begin{array}{l}250 . \\
75\end{array}$ \\
\hline & 227. & 245. & 263. & & 245 . \\
\hline & 76 & 73 & 92 & 737.41 & 80 \\
\hline
\end{tabular}

Usahatani padi yang menerapkan pertanian konvensional dengan menggunakan pupuk dan pestisida non-organik yang pengadaan dan pembuatannya tidak dilakukan oleh petani

Penggunaan Benih Padi Pada Usahatani Padi di Desa Sumber Ngepoh Kec. Lawang Kab. Malang, MT 2009-2010

\begin{tabular}{|c|c|c|c|c|c|}
\hline \multirow[b]{2}{*}{$\begin{array}{l}\text { Macam } \\
\mathrm{O}\end{array}$} & $\begin{array}{l}\text { MT } \\
\text { (kg/ha }\end{array}$ & \multicolumn{2}{|c|}{ 2009-2010 } & \multirow{2}{*}{$\begin{array}{l}\text { Total } \\
\text { Beni } \\
\text { h } \\
\text { ( } \mathrm{kg} \\
\text { / ha }\end{array}$} & \multirow{2}{*}{$\begin{array}{l}\text { Rera } \\
\text { ta } \\
(\mathrm{kg} \\
\text { /ha })\end{array}$} \\
\hline & $\begin{array}{l}\text { MK } \\
-1\end{array}$ & $\begin{array}{l}\text { MK } \\
-2\end{array}$ & MH & & \\
\hline Organik & 49.0 & 43.2 & 58.6 & 150. & 50.2 \\
\hline Mandiri & 2 & 0 & 5 & 87 & 9 \\
\hline Organik & 51.0 & 41.7 & 59.4 & 152. & 50.7 \\
\hline Tidak & 5 & 9 & 8 & 31 & 7 \\
\hline
\end{tabular}

\begin{tabular}{llllll}
\hline Mandiri & & & & & \\
\hline Transisi & 50.4 & 44.7 & 59.6 & 154. & 51.6 \\
Org. & 6 & 1 & 5 & 82 & 1 \\
Mandiri & & & & & \\
\hline Transsi & 53.5 & 48.5 & 61.3 & 163. & 54.4 \\
OrgTidak & 3 & 4 & 4 & 41 & 7 \\
Mandiri & & & & & \\
\hline Konvensio & 62.2 & 60.5 & 68.0 & 190. & 63.6 \\
nal & 6 & 4 & 3 & 84 & 1 \\
\hline & 53.2 & 47.7 & 61.4 & 162. & 54.1 \\
& 6 & 5 & 3 & 45 & 5 \\
\hline
\end{tabular}

Penggunaan Unsur Hara Pada Usahatani Padi di Desa Sumber Ngepoh Kec. Lawang Kab. Malang, MT 2009-2010

\begin{tabular}{|c|c|c|c|c|c|}
\hline \multirow[b]{2}{*}{$\begin{array}{l}\text { Macam P } \\
\mathrm{O}\end{array}$} & $\begin{array}{l}\mathrm{MT} \\
(\mathrm{kg} / \mathrm{l}\end{array}$ & \multicolumn{2}{|c|}{$2009-2010$} & \multirow{2}{*}{$\begin{array}{l}\text { Total } \\
\text { U. } \\
\text { Hara } \\
\text { (kg/h } \\
\text { a) }\end{array}$} & \multirow{2}{*}{$\begin{array}{l}\text { Rera } \\
\text { ta } \\
\text { ( } \mathrm{kg} \\
\text { /ha ) }\end{array}$} \\
\hline & $\begin{array}{l}\text { MK } \\
-1\end{array}$ & $\begin{array}{l}\text { MK } \\
-2\end{array}$ & MH & & \\
\hline $\begin{array}{l}\text { Organik } \\
\text { Mandiri } \\
\end{array}$ & $\begin{array}{l}97.0 \\
7 \\
\end{array}$ & $\begin{array}{l}100 . \\
10\end{array}$ & $\begin{array}{l}89.5 \\
1 \\
\end{array}$ & $\begin{array}{l}286 . \\
67 \\
\end{array}$ & $\begin{array}{l}95.5 \\
6 \\
\end{array}$ \\
\hline $\begin{array}{l}\text { Organik } \\
\text { Tdk } \\
\text { Mandiri }\end{array}$ & $\begin{array}{l}85.4 \\
8\end{array}$ & $\begin{array}{l}86.4 \\
6\end{array}$ & $\begin{array}{l}79.3 \\
1\end{array}$ & $\begin{array}{l}251 . \\
26\end{array}$ & $\begin{array}{l}83.7 \\
5\end{array}$ \\
\hline $\begin{array}{l}\text { Transisi } \\
\text { OrgaMan } \\
\text { diri }\end{array}$ & $\begin{array}{l}203 . \\
04\end{array}$ & $\begin{array}{l}200 . \\
82\end{array}$ & $\begin{array}{l}197 . \\
00\end{array}$ & $\begin{array}{l}600 . \\
87\end{array}$ & $\begin{array}{l}200 . \\
3\end{array}$ \\
\hline $\begin{array}{l}\text { Transsi } \\
\text { Org Tdk } \\
\text { Mandiri }\end{array}$ & $\begin{array}{l}172 . \\
94\end{array}$ & $\begin{array}{l}173 . \\
24\end{array}$ & $\begin{array}{l}161 . \\
00\end{array}$ & $\begin{array}{l}507 . \\
17\end{array}$ & $\begin{array}{l}169 . \\
1\end{array}$ \\
\hline $\begin{array}{l}\text { Konvensi } \\
\text { onal }\end{array}$ & $\begin{array}{l}241 . \\
06\end{array}$ & $\begin{array}{l}240 . \\
12\end{array}$ & $\begin{array}{l}240 . \\
47\end{array}$ & $\begin{array}{l}721 . \\
65\end{array}$ & $\begin{array}{l}240 . \\
5\end{array}$ \\
\hline & $\begin{array}{l}159 . \\
92\end{array}$ & $\begin{array}{l}160 . \\
15\end{array}$ & $\begin{array}{l}153 . \\
46\end{array}$ & $\begin{array}{l}473 . \\
52\end{array}$ & $\begin{array}{l}157 . \\
8\end{array}$ \\
\hline
\end{tabular}

Input Tenaga Kerja Usahatani Padi di Desa Sumber Ngepoh Kec. Lawang Kab. Malang, MT 2009-201 